\title{
FUNÇÃO SOCIOAMBIENTAL DA EMPRESA: FUNDAMENTOS, CONCEITO E APLICAÇÃO
}

THE SOCIAL AND ENVIRONMENTAL FUNCTIONS OF COMPANIES: FOUNDATIONS, CONCEPT AND APPLICATION

\section{FUNCIÓN SOCIOAMBIENTAL DE LA EMPRESA: FUNDAMENTOS, CONCEPTO $Y$ APLICACIÓN}

\author{
Augusto Antônio Fontanive Leal ${ }^{1 *}$
}

\author{
Carlos Alberto Molinaro ${ }^{2^{\star}}$
}

Licença CC BY:

Artigo distribuído sob os termos Creative Commons, permite uso e distribuição irrestrita em qualquer meio desde que $o$ autor credite a fonte original.

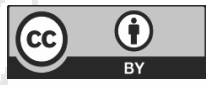

\begin{abstract}
Resumo: O presente artigo tem por objetivo dissertar sobre os fundamentos, o conceito e a aplicação da função socioambiental da empresa. Para isso, o estudo foi dividido em duas partes: a) demonstração de alguns preceitos originários da função social do direito privado, percorrendo sua consolidação no plano jurídico e terminando por descrever a função social da empresa; b) identificação do marco jurídico normativo da proteção ambiental como conformador do Estado Socioambiental de Direito, propiciando a identificação dos pressupostos da funcionalização socioambiental da propriedade, sobretudo quando direcionada às empresas. A pesquisa será qualitativa, desenvolvida pelo método hermenêutico e contará com uso de material bibliográfico e documental. Conclui-se que é possível extrair, com base em estudos da doutrina, de decisões de tribunais superiores e das normas jurídicas, a matéria basilar concernente à função socioambiental da empresa.
\end{abstract}

Palavras-chave: função socioambiental da empresa; ordem econômica; direito fundamental ao ambiente.

Abstract: I propose, in this paper, to explain the foundations, concept and application of the social and environmental functions of companies. The study is divided into two essential parts: a) demonstration of some precepts originating from the social function of private law, outlining its legal consolidation and describing the social function of the company; b) identification of the normative legal framework of environmental protection as a factor in the formation of the Social and Environmental State, allowing the identification of the premises of social and environmental functionalization of property, particularly when directed at companies. The research is qualitative, supported by the hermeneutic method, with the use of bibliographical and documentary research. Based on studies of doctrine, decisions of the Higher Courts, and the legal norms, this work concludes that it is possible to extract basic material relating to the social and environmental function of the company.

\footnotetext{
$1 \quad$ * Doutorando em Direito pela Pontifícia Universidade Católica do Rio Grande do Sul (PUCRS). E-mail: augustoafleal@gmail.com.

2 * Professor no Programa de Pós-Graduação, Mestrado e Doutorado em Direito da Pontifícia Universidade Católica do Rio Grande do Sul (PUCRS). E-mail: carlos.molinaro@pucrs.br.
} 
Keywords: social and environmental function of the company; economic order; environmental right.

Resumen: El presente artículo tiene por objetivo disertar sobre los fundamentos, el concepto y la aplicación de la función socioambiental de la empresa. Para eso, el estudio fue dividido en dos partes: a) demostración de algunos preceptos originarios de la función social del derecho privado, atravesando su consolidación en el plano jurídico y terminando por describir la función social de la empresa; b) identificación del marco jurídico normativo de la protección ambiental como conformador del Estado Socioambiental de Derecho, propiciando la identificación de los presupuestos de la funcionalización socioambiental de la propiedad, sobretodo cuando es direccionada a las empresas. La investigación será cualitativa, desarrollada por el método hermenéutico y contará con uso de material bibliográfico y documental. Se concluye que es posible extraer, con base en estudios de la doctrina, decisiones de tribunales superiores y de las normas jurídicas, la materia basilar concerniente a la función socioambiental de la empresa.

Palabras clave: función socioambiental de la empresa; orden económica; derecho fundamental al ambiente.

\section{INTRODUÇÃO}

A funcionalização do direito privado tem como uma de suas consequências a destinação social do uso da propriedade. Um direito que anteriormente era visto dotado de sacralidade e inviolabilidade passou a deixar de conter uma cláusula de domínio absoluto para ser relativizado em favor da sociedade. Surge, com isso, o contexto da função social da propriedade: a função como condicionadora a um fim de determinada ação e o social como termo utilizado para descrever a posição de destinatária da sociedade. As funções ou finalidades dos indivíduos que detêm alguma propriedade acabam se flexibilizando em favor dos interesses sociais que são afetados, direta ou indiretamente, pelo bem. Ao longo do tempo, com as relações econômicas cada vez mais fluidas e com a empresa como detentora de grandes poderes econômicos, a ideia de função social da propriedade se transmudou para a funcionalização social da empresa, considerada igualmente como propriedade, mas observada por meio da sua figura ilustrativa de bem de produção.

Não obstante a consolidação da perspectiva da função social da empresa, passa a estar constantemente presente na agenda política global a proteção do ambiente, recebendo atenção tanto em tratativas internacionais como, no caso do Brasil, também por meio da constitucionalização do direito ao ambiente. Diante disso, a ordem econômica, até mesmo por força de determinação constitucional, passou a ter como condicionante a proteção do ambiente, observado este como direito difuso e, ao mesmo tempo, dever do Estado e da coletividade, nesta última incluída a empresa. Com base nisso, foi agregado o ambiental aos fins sociais, estabelecendo a ideia de função socioambiental da empresa, anteriormente observada, igualmente em razão do direito ao ambiente constitucionalizado, como função socioambiental da propriedade. 
Com esses conceitos prévios, tem-se por objetivo descrever e fundamentar em que consistiria a função socioambiental da empresa. O texto, por sua vez, será dividido em duas partes, a primeira com a finalidade de dispor sobre a função social da empresa a partir de suas origens e percorrer pelo seu conteúdo jurídico, com atenção especial à funcionalização da propriedade no direito privado e à fundamentação sobre a função social específica da empresa. A segunda parte se destinará ao conceito da função socioambiental da empresa, que é concebida basilarmente por meio do direito ao ambiente normatizado na Constituição sem perder suas origens na função social da propriedade, o que será feito com a devida consideração da construção teórica e normativa do conceito de Estado Socioambiental e dos deveres ambientais estatais e da coletividade.

O estudo será de caráter qualitativo e como metodologia será abordado o método hermenêutico com a hipótese de ser possível extrair do ordenamento jurídico a função socioambiental da empresa. Enfim, o que se pretende demonstrar é que o direito fundamental ao ambiente alcança a ordem econômica e, com base em seu comando normativo, insere no direito privado os deveres de proteção ambiental, notadamente devido ao tema deste estudo, da função socioambiental da empresa.

\section{FUNÇÃO SOCIAL DA EMPRESA: ORIGENS E CONTEÚDO}

A função social da empresa tem origens em diversas teorizações anteriores que não necessariamente remetem ao plano jurídico, a exemplo das propostas de Comte, Renner e Duguit. Além disso, encontra sua perspectiva, atualmente derivada para vincular a empresa, na originária concepção da função social da propriedade.

Sendo assim, propõe-se nesta primeira seção realizar uma análise da ideia de funcionalização do direito privado, partindo de suas origens, passando pela sua concretização atual no ordenamento jurídico brasileiro, até alcançar, por fim, o conceito de função social da empresa.

\subsection{PROPRIEDADE E FUNCIONALIZAÇÃO DO DIREITO PRIVADO}

A ideia de dar função a algo se direciona inevitavelmente à atribuição de uma atividade finalística. Funcionalizar remete à possibilidade de dar um específico fim que não necessariamente coincida com o objetivo essencial a que algo se destina. Portanto, o preceito contido no termo social, quando agregado ao aspecto funcional, formando a expressão função social, demonstra que a sociedade aparece como a destinatária desta atividade fim que se deseja. 
Importante esclarecer que nem sempre o conceito de função social, tão recorrente no direito, foi a ele pertencente, nem mesmo deita no cenário jurídico suas raízes. O instituto da função social concebido no direito privado contemporâneo não deixa de ter suas bases em uma construção teórica desenvolvida a partir de diferentes matizes teóricas propostas, por exemplo, por Comte, Renner e Duguit, ainda que não reconheça especificamente, em sua composição, algum dos antigos fundamentos que Ihe deram origem. Até alcançar a área própria do direito, o conceito de função social transitou pelas áreas da filosofia, da política e da sociologia, de onde se extraíram diversas perspectivas.

Considerada como uma das primeiras teorizações a respeito da função social está aquela formulada por Comte em suas teorias positivistas. Comte toma como exemplo o instituto da propriedade para exemplificar que, antes da adoção de medidas políticas, a solução para resolver os problemas criados pelo reconhecimento da propriedade estaria em uma reorganização intelectual e moral. ${ }^{3}$ Ainda segundo o positivista, o cidadão seria uma espécie de funcionário público com deveres e atribuições determinadas pelas suas capacidades, donde a propriedade estaria inclusa neste princípio universal, dotada de uma função social de criar e administrar o capital em que cada geração atuaria para a próxima. ${ }^{4}$

Percebe-se, por meio destas duas passagens extraídas da teoria positivista comtiana, a concepção de uma reestrutura social com base na reforma moral e intelectual dos cidadãos que deixariam de ser meros membros do corpo social e passariam a contar com deveres de agir voltados ao exercício de funções públicas em benefício da sociedade, isto é, realizariam cada qual sua função social. Deste modo, a ação dos cidadãos não seria somente composta de fins individuais, mas conteria em suas finalidades atividades exercidas em benefício de toda a sociedade.

Renner, apoiado em seus estudos de cunho marxista e voltado para o papel social desempenhado pelos agentes econômicos da sociedade, também fora um dos precursores da teoria da função social em estudo realizado sobre as instituições e as funções do direito privado. Conforme o autor, a função social das instituições legais e, por conseguinte, do direito, corresponderia à função econômica presente no processo de produção e reprodução social. ${ }^{5}$ Nesta visão, a função social dos institutos jurídicos inarredavelmente reproduziria a função econômica da sociedade e, mesmo de modo mais abstrato, seria um espelho dos processos econômicos. O pensamento de Renner é ilustrado pela sua compreensão de que as leis e as instituições econômicas seriam dois aspectos da mesma

3 COMTE, Auguste. The Positive Philosophy of Auguste Comte. Translated and condensed by Harriet Martineau. Kitchener: Batoche Books, 2000, p. 150.

4 COMTE, Auguste. A general view of positivism. Translated by J. H. Bridges. Cambridge: Cambridge University Press, 2009, p. 165-166.

5 RENNER, Karl. The institutions of private law and their social functions. Translated Agnes Schwarzschild. London: Routledge \& Kegan Paul Limited, 1949, p. 57-58. 
composição, mutuamente determinadas. ${ }^{6}$ Assim, em uma análise processual histórica, Renner aponta essa inextricável relação e concebe a função social como uma expressão direta da função econômica.

Desde logo se percebe que a vinculação entre direito e economia prevista por Renner não encontra correspondência fática na realidade e descuida da ideia do direito a partir de um critério de dever ser. Com as devidas considerações da realidade política, social e econômica, não se pode olvidar a força normativa dos preceitos jurídicos, como demonstrado por Hesse no tocante à pretensão de eficácia da Constituição. ${ }^{7}$ Duguit, por sua vez, igualmente comporá a ideia de função social, com base na ideia de que o mero nascimento em sociedade geraria vínculos de solidariedade social que fundamentaria deveres de solidariedade. De acordo com a visão de Duguit, apresentada com forte influência proveniente do positivismo de Comte, a ideia de propriedade repousaria unicamente em sua utilidade social, de forma a transformar o direito subjetivo de propriedade em uma função social da propriedade. Caso o proprietário não cumprisse com sua função social, não teria para si assegurada a sua apropriação. ${ }^{8}$ Duguit não se posicionava contra a propriedade, mas insistia que seu uso deveria alcançar toda a sociedade, por conceber o aumento do capital individual como um benefício para todo o corpo social com o incremento da riqueza geral, dando forma ao que seria não mais uma propriedade como direito, mas uma propriedade-função ${ }^{9}$. Esta estaria associada ao uso como forma de aumento de riquezas, somente legitimando a propriedade com o cumprimento desta função social.

Ao longo do tempo, percebe-se que o conceito de função social, normalmente associado ao instituto da propriedade, vai se aproximando do meio jurídico e, especificamente, do direito privado, sem que se desconsidere a existência de pressupostos da função social contidos na perspectiva de desempenho da função pública, como se observa dos fins da administração pública voltados ao objetivo do bem comum da coletividade. ${ }^{10}$ Diferentemente do direito privado, porém, nos casos que envolvem a administração pública, subsiste a característica própria do exercício de atividades de interesse público, qual seja de esvaziamento do interesse particular daquele investido nos encargos administrativos.

A aproximação do conceito de função social aos contornos do direito privado toma forma com Renner ou mesmo Duguit, sem que se desconsiderem as ideias originárias perpetradas, por exemplo, na Itália por Enrico Cimbali ou na Alemanha, pelo trabalho de Otto Von Gierke. ${ }^{11}$ Permeia

6 RENNER, Karl. The institutions of private law and their social functions. Translated Agnes Schwarzschild. London: Routledge \& Kegan Paul Limited, 1949, p. 58.

HESSE, Konrad. A força normativa da Constituição. Tradução de Gilmar Mendes. Porto Alegre: Sergio Antonio Fabris Editor, 1991, p. $15-16$. DUGUIT, Léon. Traité de Droit Constitutionnel. 2. ed. Tome Troisiéme. Paris: E. de Boccard, 1923, p. 618.

Ibidem, p. 620

MEIRELLES, Hely Lopes. Direito administrativo brasileiro. 43. ed. São Paulo: Malheiros, 2018, p. 89.

FACCHINI NETO, Eugênio; ANDRADE, Fábio Siebeneichler de. A funcionalização do direito: a empresa e sua função social. In: STEINDORFER, Fabriccio; MIZUTA, Alessandra. Limitações constitucionais ao exercício da atividade econômica. Curitiba: Juruá, 2016 , p. 20. 
essas concepções a contextualização da função social dos institutos de direito privado como um rompimento com o modelo individualista das codificações liberais oitocentistas mediante a adoção da função do direito desempenhada no meio social como premissa para os processos de análise jurídica. ${ }^{12}$ Com o desenvolvimento de propostas de funcionalização de institutos de direito privado com nítida finalidade de benefício social, mormente sobre a propriedade, percebe-se um direcionamento a vertentes solidárias. De fato, desde ideias filosóficas até a aplicação da função social sobre a ambiência jurídica e, portanto, coligada às questões fático-normativas, pressupõe-se uma fundamentação calcada em parâmetros de solidariedade. Pela compreensão do viés solidário que inevitavelmente toma assento no direito, são fornecidos aportes para a conjugação entre a natureza individual humana e sua inserção na coletividade.

Um dos pontos de partida do processo de funcionalização especificamente do direito privado começa a ser considerado por meio da ideia de solidariedade, apesar de se destacar não ter sido na configuração do Estado Social que se tenha concluído o projeto conformador da função social no plano jurídico de diferentes países. Com efeito, de acordo com Sarlet, o Estado Social previsto, mas sem exclusividade, na Constituição brasileira depende de direitos fundamentais sociais que contenham exigências de efetivo exercício de liberdades e garantias de igualdade de oportunidades ${ }^{13}$, associando essa vertente como o fortalecimento, no âmbito de direitos fundamentais de segunda dimensão, do princípio da justiça social. ${ }^{14}$ Como critério de solidariedade, subsiste no artigo $3^{\circ}$, inciso I, da Constituição, o objetivo fundamental de construção de uma sociedade solidária. Já a justiça social é, a rigor, o parâmetro balizador da ordem econômica, conforme determina o caput do artigo 170 da Constituição.

A conformação do princípio da justiça social como um dos pressupostos da funcionalização do direito privado e os preceitos axiológicos desenvolvidos ao longo do processo histórico motivaram, em maior ou menor grau, a atual concepção jurídica de função social que permeia o direito privado. No ordenamento jurídico brasileiro podem ser mencionadas, a título exemplificativo, a função social do contrato (artigo 421, do Código Civil), a função social da família, a função social da propriedade (artigo $1.228, \S 1^{\circ}$, do Código Civil; artigo $5^{\circ}$, inciso XXII, artigo $182, \S 2^{\circ}$ e 184 , todos da Constituição) ${ }^{15}$, a função social da responsabilidade civil e, como objeto pertinente ao presente estudo, a função social da empresa. ${ }^{16}$

12 TIMM, Luciano Benetti. As origens do contrato no novo Código Civil: uma introdução à função social, ao welfarismo e ao solidarismo contratual. Revista dos Tribunais, v. 844, p. 85-95, fev. 2006, p. 1. Disponível em: <http://www.pucrs.br/biblioteca/rtonline>. Acesso em 15 ago. 2018.

13 SARLET, Ingo Wolfgang. A eficácia dos direitos fundamentais: uma teoria geral dos direitos fundamentais na perspectiva constitucional. 11. ed. Porto Alegre: Livraria do Advogado Editora, 2012, p. 62.

$14 \quad$ Ibidem, p. 48.

15 Importante recordar que a positivação da função social da propriedade se deu com a Constituição alemã de Weimar, do ano de 1919, em parte da redação normativa do artigo 153 que em tradução livre significa: "A propriedade obriga. Seu uso também deve servir ao bem comum." (Eigentum verpflichtet. Sein Gebrauch soll zugleich Dienst sein für das Gemeine Beste). (VERFASSUNG des Deutschen Reichs. Bonn, 11 August 1919. Disponível em: <http://www.lwl.org/westfaelische-geschichte/que/normal/que843.pdf>. Acesso em: 16 ago. 2018).

16 Sobre a identificação detalhada dos principais institutos do direito privado observados quanto a sua funcionalização e socialização, consta o capítulo de Facchini Neto, intitulado 'Função social do direito privado', presente na coletânea 'Função social do direito' (FACCHINI NETO, Eugênio. A função social do direito privado. TIMM, Luciano Benetti; MACHADO, Rafael Bicca. Função Social do Direito. São Paulo: Quartier Latin, 2009, p. 111-156.). Ver, também, sobre a funcionalização do direito privado, especificamente no caso dos contratos, a concepção de Moura sobre o interesse coletivo revestido de regras de ordem pública com conteúdo inafastável pelos contratantes (MOURA, M. A. Função social do contrato. Revista dos Tribunais, v. 630, p. 247-249, abr. 1988, p. 248-249.). 
Não se pode olvidar que, de todas as formas de funcionalização no âmbito do direito privado, chama atenção aquela afeita ao direito de propriedade, inclusive devido suas históricas relações com a função social. É neste instituto que, como se procurou demonstrar, serviram-se como exemplo a maioria das realizações teóricas sobre a função social, principalmente ao demonstrar sua consagração no caso das matérias próprias ao direito privado. O próximo tópico a ser abordado, concernente à função social da empresa, por sua vez, tampouco deixa de lembrar em sua conceituação os laços com a funcionalização do direito de propriedade, sendo dele proveniente.

\subsection{FUNÇÃO SOCIAL DA EMPRESA}

Embora não exista uma previsão normativa específica e geral da função social da empresa, a ideia de extensão da função social concebida sobre a propriedade para albergar, em seu comando impositivo, também as empresas, pode ser analisada com base na doutrina de Comparato e da divisão proposta entre bens de produção e bens de consumo. Enquanto estes são bens presentes no final do ciclo distributivo, aqueles englobam a totalidade do fundo de comércio, daí se podendo extrair que a classificação dos bens em produtivos ou de consumo depende da devida análise da destinação que lhes é dada. ${ }^{17}$

Tratando-se de bens de produção e tendo em conta seu significado, por meio do critério da função social, seria explicada, por exemplo, a desapropriação como sanção para grandes latifúndios improdutivos. É neste contexto que Comparato vai assentar a possibilidade de existência da função social da empresa. Ao afirmar que a função social do proprietário corresponde a um poder-dever ${ }^{18}$, reconhece o autor que, em se tratando de bens incorporados à exploração empresarial, o poderdever seria desempenhado pelo titular do controle de dirigir a empresa. ${ }^{19}$ Mesmo assim, Comparato vai expressar pessimismo quanto ao instituto, buscando apontar uma incongruência entre o reconhecimento da função social e o objetivo da eficiência lucrativa das empresas. ${ }^{20}$

Estabelecendo uma diferenciação entre a função individual da propriedade, idealizada como aquela desempenhada para provimento de subsistência familiar e a função social da empresa, concebida sobre os bens de produção postos em dinamismo no regime de uma atividade empresarial, Grau disporá sua concepção de função social de maneira compatível com as lições de Comparato. ${ }^{21}$

\footnotetext{
17 COMPARATO, Fábio Konder. Função social da propriedade dos bens de produção. In: Comparato, Fábio Konder. Direito empresarial: estudos e pareceres. São Paulo: Saraiva, 1990, p. 29.

18 Ibidem, p. 32. Para o autor, porém, a função social, como poder-dever, representaria somente a esfera positiva de ações ou cumprimentos de obrigações, enquanto se entende, neste estudo, que a função social vai alcançar, igualmente, a esfera negativa, isto é, do não agir em prejuízo ou desconformidade com as normas concernentes à função social.

19 Ibidem, p. 34

20 COMPARATO, Fábio Konder. Estado, Empresa e Função Social. Revista dos Tribunais, v. 732, p. 38-46, out. 1996, p. 6. Disponível em: <http:// www.pucrs.br/biblioteca/rtonline>. Acesso em: 16 ago. 2018.

21 GRAU, Eros Roberto. A ordem econômica na Constituição de 1988: interpretação e crítica. 18. ed. São Paulo: Malheiros, 2017, p. 235-236.
} 
A noção de bens de produção auxilia a depreender, mesmo genericamente, uma justificativa para se imputar às empresas os deveres concernentes à função social. Além disso, a empresa, alçada à posição de um sujeito de direitos, interage na esfera social mediante vínculos com terceiros ${ }^{22}$, do que decorre que assim como goza de direitos, por outro lado, deve ela cumprir com deveres decorrentes do ordenamento jurídico a que está inserida. Extraída a noção geral e o conteúdo proveniente da vinculação da atividade econômica com os propósitos da função social da propriedade (artigo 170 da Constituição) e tomando por base a construção elaborada por Nabais, de se considerar que a essencialidade de deveres fundamentais, embora baseada nas posições jurídicas individuais, não deixa de lado a possibilidade de que pessoas coletivas tenham de cumprir com deveres, reconhecendo a eminente dignidade dos indivíduos que agem em nome delas. ${ }^{23}$ Ressalve-se, contudo, que a imputação de deveres fundamentais às pessoas jurídicas revela extensão ou densidade diversa dos deveres individuais, como é o típico caso do dever de proteção ambiental quando sujeita pessoas coletivas. ${ }^{24} \mathrm{~A}$ função social não se limita a ter como destinatário indivíduos, devendo ser compreendida extensivamente com a imputação de deveres também às pessoas jurídicas e, com destaque em razão deste estudo, às empresas.

Como anteriormente referido, não existe no ordenamento jurídico pátrio uma previsão explícita e geral a respeito do princípio da função social para todas as empresas ${ }^{25}$. Isso não significa dizer, entretanto, que referido princípio não esteja presente em disposições normativas, tampouco que seja impossível destacar sua existência por meio da interpretação de preceitos contidos na estrutura de normas do direito privado ou previstas na Constituição.

Dentre as aparições do princípio da função social da empresa estão duas previsões contidas na Lei das Sociedades Anônimas (Lei 6.404/1976). A primeira, no artigo 116, parágrafo único, condiciona a atividade do acionista controlador ao cumprimento, além do objeto da companhia, da função social. Posteriormente, o artigo 154 refere que o administrador tem por dever satisfazer as exigências da função social da empresa.

Além das previsões contidas nos artigos da Lei das Sociedades Anônimas, não se pode desconsiderar a disposição jusfundamental do dever de cumprimento da função social da propriedade

\footnotetext{
22 FACCHINI NETO, Eugênio; ANDRADE, Fábio Siebeneichler de. A funcionalização do direito: a empresa e sua função social. In: STEINDORFER, Fabriccio; MIZUTA, Alessandra. Limitações constitucionais ao exercício da atividade econômica. Curitiba: Juruá, 2016, p. 23

NABAIS, José Casalta. O dever fundamental de pagar impostos. Coimbra: Livraria Almedina, 1998, p. 69.

Ibidem, p. 70.

Propondo suprir esta lacuna normativa, tramitou na Câmara dos Deputados o Projeto de Lei 6.960/2002, de autoria do deputado Ricardo Fiúza, que visava, vários dispositivos, anexar um segundo parágrafo ao artigo 966 do Código Civil, com a seguinte redação: "§ $2^{\circ} \mathrm{O}$ exercício da atividade de empresário, fundada na valorização do trabalho humano e na livre iniciativa, observará os limites impostos pelo seu fim econômico ou social, pela boa fé e pelos bons costumes". O projeto, porém, acabou sendo arquivado por ainda estar em tramitação quando findou a legislatura, em atenção ao artigo 105 do Regimento Interno da Câmara dos Deputados. (BRASIL. Câmara dos Deputados. Projeto de Lei 6960/2002. Disponível em: <http://www.camara.gov.br/proposicoesWeb/ fichadetramitacao?idProposicao=56549>. Acesso em: 17 de agosto de 2018).
} 
prevista no artigo $5^{\circ}, \mathrm{XXIII}$, da Constituição, assim como do princípio da função social da propriedade, observado como condicionador da ordem econômica, no artigo 170, III, igualmente da Constituição.

De certo que a expressão função social da propriedade não especifica necessariamente alguma espécie de bem patrimonial, se é bem móvel ou imóvel, público ou privado. A respeito disso, importante recordar que nos comentários à Constituição de 1967, Pontes de Miranda classificou como direito de propriedade qualquer direito patrimonial. ${ }^{26}$ Deste modo, tem-se que a funcionalização social da propriedade é teia que se espraia por diversos institutos patrimoniais do direito, principalmente na esfera do direito privado, de modo a se reconhecer que sua amplidão atinge as empresas.

Não é tarefa tão fácil, porém, definir o conteúdo do princípio função social da empresa. Para o caso das empresas sob controle do Estado ou, mais especificamente, empresas públicas e sociedades de economia mista, o interesse público que deu causa a sua criação é que determinaria a sua função social. ${ }^{27}$ Não obstante, entende-se que, mesmo assim, seriam aplicáveis às empresas estatais lato sensu não somente os objetivos do interesse público, mas em regra, aplicar-se-iam igualmente os parâmetros destinados às empresas privadas, em razão das estatais conterem regime jurídico próprio de empresas privadas, inclusive as mesmas obrigações (artigo 173, §1, II, da Constituição), bem como, por analogia, em razão de lhes serem vedados privilégios fiscais não extensíveis às empresas privadas (artigo 173, $\S 2^{\circ}$, da Constituição). E qual seria o conteúdo do princípio da função social da empresa aplicável às empresas de regime jurídico privado?

Seguindo a orientação de Tomasevicius Filho ${ }^{28}$, os deveres subjacentes ao exercício da função social da empresa têm como parâmetro o conteúdo normativo do artigo 170 da Constituição, tratandose de disposições referentes à ordem econômica. Segundo o citado artigo, devem ser observadas, no critério geral da ordem econômica, a valorização do trabalho humano e a livre iniciativa, com a garantia de que todos tenham uma existência digna, segundo a observância da justiça social e atendendo aos princípios da soberania nacional, propriedade privada, função social da propriedade, livre concorrência, defesa do consumidor, defesa do ambiente, redução de desigualdades regionais e sociais, busca do pleno emprego e tratamento favorecido para empresas de pequeno porte.

Os ditames do artigo 170, inclusive os princípios apontados, que não esgotam o sentido da função social da empresa ${ }^{29}$, oferecem uma base de fundamentação para as diversas possíveis expressões da função social da empresa no plano concreto. São efeitos que irradiam em decorrência

26 PONTES DE MIRANDA. Comentários à Constituição de 1967: com a emenda n. 1, de 1969. Tomo V (arts. 153, §2 , - 159). 2. ed. São Paulo: Editora Revista dos Tribunais, 1971, p. 398.

27 GRAU, Eros Roberto. Lucratividade e função social das empresas sob controle do Estado. Revista de Direito Mercantil, Industrial, Econômico e Financeiro, v. XXIII, n. 55, p. 35-59, jul./set. 1984, p. 58.

28 TOMASEVICIUS FILHO, Eduardo. A função social da empresa. Revista dos Tribunais, v. 810, p. 33-50, abr. 2003, p. 9. Disponível em: <http:// www.pucrs.br/biblioteca/rtonline>. Acesso em: 16 ago. 2018.

29 FRAZÃO, Ana. Função social da empresa: repercussões sobre a responsabilidade civil de controlares e administradores de S/As. Rio de Janeiro: Renovar, 2011, p. 198. 
da funcionalização da atividade empresarial e podem conter diversos significados. Um dos aspectos constitui matéria de proteção à própria empresa, quando do reconhecimento de sua importância econômica e social. ${ }^{30}$ Dentre as hipóteses que decorrem dessa vertente está a possibilidade de recuperação judicial de empresas em processo falimentar, donde ressai o procedimento diferenciado com o intuito de manter a atividade empresarial justamente em favor do contributo social de seu exercício, como reconhecem Cretella Neto ${ }^{31}$, Fazzio Júnior ${ }^{32}$ e Scalzilli, Spinelli e Tellechea ${ }^{33}$.

Como exemplo de caso em que o princípio da função social da empresa é empregado em defesa da atividade empresarial, tem-se o reconhecimento da negativa de pedido de falência da Fazenda Pública contra empresas, em função do interesse do Estado na sua conservação, como fora decidido pelo Superior Tribunal de Justiça. ${ }^{34}$ Outro caso que serve como exemplo versa sobre a impossibilidade de pedido de falência por valor insignificante, também reconhecido pelo Superior Tribunal de Justiça. ${ }^{35}$

É possível mencionar, ainda, a função social da empresa em relação aos empregados, com fundamento no princípio geral da busca ao pleno emprego que está inserido nos princípios gerais da ordem econômica, constante no artigo 170, inciso VIII, da Constituição, além dos direitos fundamentais positivados no artigo $7^{\circ}$, também da Constituição. Além de servir como fundamento de proteção da empresa, o princípio da função social se apresenta como mecanismo de implementação de deveres externos. ${ }^{36}$ A atividade empresarial, por força do princípio da função social, é condicionada no seu exercício pelos mandamentos da justiça social, concebida como meio de reinserção da solidariedade social na atividade econômica. ${ }^{37}$

Justifica-se a imposição de deveres externos pelo conteúdo do artigo 170 da Constituição e pelos traços que transcendem a previsão constitucional e alcançam o direito privado diretamente,

30 FACCHINI NETO, Eugênio; ANDRADE, Fábio Siebeneichler de. A funcionalização do direito: a empresa e sua função social. In: STEINDORFER, Fabriccio; MIZUTA, Alessandra. Limitações constitucionais ao exercício da atividade econômica. Curitiba: Juruá, 2016, p. 26-30; FRAZÃO, Ana. Função social da empresa: repercussões sobre a responsabilidade civil de controlares e administradores de S/As. Rio de Janeiro: Renovar, 2011, p. 214-220.

31 CRETELLA NETO, José. Nova lei de falências e recuperação de empresas: lei no 11.101, de 09.02.2005. Rio de Janeiro: Forense, 2005, p. 9

32 FAZZIO JÚNIOR, Waldo. Nova lei de falência e recuperação de empresas. 2. ed. São Paulo: Atlas, 2005, p. 25.

33 SCALZILLI, João Pedro; SPINELLI, Luis Felipe; TELLECHEA, Rodrigo. Recuperação de empresas e falência: teoria e prática na Lei 11.101/2005. São Paulo: Almedina, 2016, p. 72-73.

34 BRASIL. Superior Tribunal de Justiça. Recurso Especial n 363.206 - MG. Recorrente: Fazenda Pública do Estado de Minas Gerais. Recorrido: Royal Minas Distribuidora LTDA. Relator: Ministro Humberto Martins. Brasília, 04 de maio de 2010. Disponível em: <https://ww2.stj.jus.br/ processo/revista/documento/mediado/? componente=ATC\&sequencial $=9876145 \&$ num_registro $=200101482710 \&$ data $=20100521 \&$ tipo $=5 \&$ for mato=PDF>. Acesso em: 20 ago. 2018

35 BRASIL. Superior Tribunal de Justiça. AgRg no Agravo de Instrumento n 1.022 .464 - SP. Agravante: Cipatex Impregnadora de Papéis e Tecidos LTDA. Agravado: Calçados E G M LTDA - Microempresa. Relator: Ministro Aldir Passarinho Júnior. Brasília, 02 de junho de 2009. Disponível em: <https://ww2.stj.jus.br/processo/revista/ documento/mediado/?componente=ATC\&sequencial=5301121\&num_registro=200800 459448\&data=20090629\&tipo=5\&formato=PDF>. Acesso em: 20 ago. 2018.

36 FACCHINI NETO, Eugênio; ANDRADE, Fábio Siebeneichler de. A funcionalização do direito: a empresa e sua função social. In: STEINDORFER, Fabriccio; MIZUTA, Alessandra. Limitações constitucionais ao exercício da atividade econômica. Curitiba: Juruá, 2016, p. 30-36.

37 FRAZÃO, Ana. Função social da empresa: repercussões sobre a responsabilidade civil de controlares e administradores de S/As. Rio de Janeiro: Renovar, 2011, p. 200. De acordo com Grau, a justiça implicaria, inicialmente, em pressupostos microeconômicos de superação de injustiças quando da repartição a nível pessoal do produto econômico e, posteriormente, passaria a um critério macroeconômico de correção de injustiças da repartição não somente observadas como imposição ética, mas como exigência da política econômica capitalista (GRAU, Eros Roberto. A ordem econômica na Constituição de 1988: interpretação e crítica. 18. ed. São Paulo: Malheiros, 2017, p. 222). 
contando com diversos deveres que são cumpridos pelas empresas. Da atenção ao postulado dos deveres das empresas, constata-se que os deveres imputáveis à atividade empresarial não se restringem ao seu ambiente interno e, portanto, afetam diversos segmentos da sociedade, com maior ou menor contato. São diversos campos possíveis de atuação, dentre eles o direito consumerista e o direito ambiental, sendo este último o tema específico deste estudo a ser retratado mais adiante.

O norte que se tem apontado quando da necessidade de desempenho da atividade empresarial sem menoscabar os ditames da justiça social é justamente o princípio da função social da empresa. Ressalte-se, porém, que em nenhum momento os preceitos sociais contidos na funcionalização da atividade empresarial indicam uma desconsideração de sua tarefa primordial de obtenção de lucro, o que seria inclusive vedado pela Constituição que preza pela livre iniciativa. Deve-se, igualmente, ter o devido cuidado com os ônus que se impõem às empresas, sob risco de onerá-las em demasia e impedir a atividade lucrativa, considerando-se, ainda, que os seus custos acabariam repassados nos preços finais de produtos e serviços, atingindo toda a sociedade consumerista.

A respeito da imposição de deveres justificados com base na função social, menciona-se decisão do Supremo Tribunal Federal no julgamento de constitucionalidade do pagamento de meia-entrada para estudantes no qual se reconheceu que, conjuntamente à livre iniciativa, deve-se considerar o direito à educação, à cultura e ao desporto com a preservação do interesse da coletividade. ${ }^{38}$

É claro que tanto a ideia de preservação da empresa como o estabelecimento de deveres externos à atividade empresarial representam segmentos da expressão do princípio da função social da empresa que pode servir como fundamento para outras disposições também aplicáveis à atividade empresarial.

Portanto, conceitualmente, pode-se dizer que a função social da empresa é princípio que se extrai, formal e materialmente, da legislação constitucional e ordinária, afigurando-se como um poder-dever da empresa na realização de deveres positivos e negativos e serve, igualmente, tendo em conta o reconhecimento do contributo desempenhado pelas empresas no cenário econômico e social, como base justificativa para sua proteção.

38 BRASIL. Supremo Tribunal Federal. Ação Direta de Inconstitucionalidade 1950 - SP. Requerente: Confederação Nacional do Comércio - CNC Requerido: Governador do Estado de São Paulo. Requerida: Assembleia Legislativa do Estado de São Paulo. Relator: Ministro Eros Grau. Brasília, 03 de novembro de 2015. Disponível em: <http://redir.stf.jus.br/paginadorpub/paginador.jsp?docTP=AC\&docID=2668080>. Acesso em: 20 ago. 2018. 


\section{FUNCIONALIZAÇÃO SOCIOAMBIENTAL DA EMPRESA}

Com a constitucionalização do direito ao ambiente e a importância de que se dota esta norma constitucional, reformando a posição do Estado para agregar-Ihe como função das mais primordiais a tutela ambiental, dizer somente em função social da empresa descuidaria de matéria de relevante apelo no ordenamento jurídico pátrio.

Por isso, objetivando dispor sobre o que trataria a funcionalização socioambiental da empresa, pretende-se neste capítulo dispor, inicialmente, sobre o direito fundamental ao ambiente e, após, demonstrar como a função social da empresa se transmuda em função socioambiental em razão da jusfundamentalização da tutela do ambiente.

\subsection{CONSIDERAÇÕES SOBRE O DIREITO FUNDAMENTAL AO AMBIENTE}

Da metade do século XX em diante começam a ganhar volume as reivindicações ambientais. Diante disso, a agenda internacional passou a considerar com maior ênfase, no âmbito da tutela ambiental, a proteção do ser humano, revelando a importância dos instrumentos internacionais sobre direitos humanos. ${ }^{39} \mathrm{O}$ ambiente passou a tomar conta da agenda política internacional e em decorrência disso surgiram diversas formas de regulação de práticas ambientais e deveres estatais.

Portanto, o caminho da proteção ambiental acabou sendo trilhado, de início, por intermédio de mecanismos de regulação do direito internacional, inclusive com a consagração do reconhecimento de um direito a viver em um ambiente com equilíbrio que propicie a vida.

Observando a convergência havida entre a consolidação internacional de direitos humanos, os processos de constitucionalização e a problemática ambiental reconhecida e existente, pode-se dizer que mesmo sendo recente, subsiste um extenso reconhecimento, tanto no cenário internacional como no âmbito interno de países por meio de leis e Constituições do direito ao ambiente. Um levantamento realizado com dados posteriores à Declaração de Estocolmo de 1972 comprova essa situação ao demonstrar a adoção de medidas de tutela ambiental em 147 constituições nacionais. ${ }^{40}$

No ordenamento jurídico brasileiro não se deu de forma diferente. O ambiente, ao ser inserido no texto constitucional, demonstra o ideal constituinte de tratar sobre este tema como res maximi momenti, sendo em razão disso que, direta e indiretamente, explícita ou implicitamente,

39 TRINDADE, Antônio Augusto Cançado. Tratado de Direito Internacional dos Direitos Humanos. 3 v. Porto Alegre: Sergio Antonio Fabris Editor, 2003.

40 BOYD, David. The environmental rights revolution: a global study of constitutions, human rights, and the environment. Vancouver: UBC Press, 2012, p. 279 
são encontrados no ordenamento constitucional os fundamentos da proteção ambiental e de sua qualidade. ${ }^{41} \mathrm{O}$ reconhecimento da importância do ambiente para a existência humana justifica a necessidade de sua inclusão no conjunto de direitos fundamentais. ${ }^{42}$ Por essa razão, de acordo com Sarlet e Fensterseifer, a influência do direito constitucional estrangeiro e a do direito internacional reforçaram a positivação, no bojo da Constituição brasileira, da base normativa do constitucionalismo ambiental, consolidando o direito ao ambiente. ${ }^{43}$

Como explica Gavião Filho, a posição de direito fundamental do direito ao ambiente contém sua demonstração por meio de uma justificação jusfundamental ${ }^{44}$. Para isso, leva-se em conta o artigo $5^{\circ}, \S 2^{\circ}$ da Constituição, que fornece uma abertura material para o catálogo de direitos fundamentais, aliado ao reconhecimento da posição fundamental jurídica definitiva passível de exigênciajurisdicional, para se concluir que a disposição normativa contida no artigo 225 , da Constituição é a de um direito fundamental, então denominado direito fundamental ao ambiente..$^{45}$

Como um feixe de posições de direitos fundamentais unidas em uma disposição de direito fundamental ${ }^{46}$, a análise estrutural do direito fundamental ao ambiente compreende um direito a algo que, por sua vez, decompõe-se em direitos a ações negativas (de defesa) ${ }^{47}$ e a ações positivas (de prestações fáticas ou normativas). ${ }^{48}$ Trata-se de um direito com duas dimensões, donde a dimensão subjetiva remete à possibilidade do titular do direito exercê-lo judicialmente ${ }^{49}$ e a dimensão objetiva contém e expressa valores objetivos fundamentais da coletividade ${ }^{50}$, além de ordenar ao Estado que concretize e realize os direitos fundamentais ${ }^{51}$. Assim, o direito fundamental ao ambiente, na sua composição, conta com uma configuração normativa integrada e multidimensional de proteção e promoção que objetiva a sua máxima eficácia e efetividade ${ }^{52}$.

O Supremo Tribunal Federal se pronunciou pelo reconhecimento do ambiente como um direito de terceira dimensão, com conteúdo de valor fundamental indisponível e prerrogativa jurídica de titularidade coletiva. Assim foi declarado nas primeiras decisões a respeito do tema após a constitucionalização do ambiente no direito brasileiro, como evidenciam os votos do Ministro Celso

\footnotetext{
41 MILARÉ, Édis. Direito do ambiente. 9. ed. São Paulo: Editora Revista dos Tribunais, 2014, p. 160-161.

42 PÉREZ LUÑO, Antonio Enrique. Derechos Humanos, Estado de Derecho y Constitucion. 5. ed. Madrid: Tecnos, 1995 , p. 463.

43 SARLET, Ingo Wolfgang; FENSTERSEIFER, Tiago. Direito Constitucional Ambiental: constituição, direitos fundamentais e proteção do ambiente. 3. ed. São Paulo: Editora Revista dos Tribunais, 2013, p. 48

GAVIÃO FILHO, Anizio Pires. Direito fundamental ao ambiente. Porto Alegre: Livraria do Advogado, 2005, p. 32.

Ibidem, p. 36-37.

ALEXY, Robert. Teoria dos direitos fundamentais. Tradução de Virgílio Afonso da Silva. 2. ed. São Paulo: Malheiros Editores, 2011, p. 249.

Ibidem, p. 196.

Ibidem, p. 201.

SARLET, Ingo Wolfgang. Teoria geral dos direitos fundamentais. In: SARLET, Ingo Wolfgang; MARINONI, Luiz Guilherme; MITIDIERO, Daniel. Curso de direito constitucional. 6. ed. São Paulo: Saraiva, 2017, p. 349.

50 SARLET, Ingo Wolfgang. A eficácia dos direitos fundamentais: uma teoria geral dos direitos fundamentais na perspectiva constitucional. 11. ed. Porto Alegre: Livraria do Advogado Editora, 2012, p. 145.

51 bidem, p. 146.

52 SARLET, Ingo Wolfgang; FENSTERSEIFER, Tiago. Direito constitucional ambiental: constituição, direitos fundamentais e proteção do ambiente. 3. ed. São Paulo: Editora Revista dos Tribunais, 2013, p. 66-67.
} 


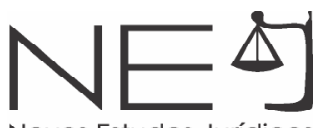

de Mello, inicialmente no Recurso Extraordinário $134.297^{53}$ e, posteriormente, com aprofundamento na fundamentação, na decisão do Mandado de Segurança $22.164^{54}$.

O direito fundamental ao ambiente não se esgota na perspectiva subjetiva e objetiva apontadas. Revela um conteúdo de imprescindibilidade de atuação da coletividade, fazendo-o por meio da imposição dos deveres fundamentais ambientais. Em outras palavras, a proteção do ambiente não advém somente do Estado, mas depende de todos os cidadãos ${ }^{55}$, como se extrai da redação normativa do artigo 225 da Constituição.

Como ilustram Canotilho e Moreira, o dever de defesa do ambiente assume três vertentes: (1) obrigação de não agir contra o ambiente; (2) obrigações positivas diversas; (3) dever de impedir os atentados ambientais de terceiros contra o ambiente pela via judicial. ${ }^{56}$ As três vertentes demonstradas expressam que a coletividade, além de não agir em prejuízo do ambiente, deve agir em benefício do ambiente.

Significa dizer que o comando normativo expresso no artigo 225 da Constituição confere uma estrutura de conduta que impõe aos cidadãos o cumprimento do dever fundamental ambiental, sem transgredir os limites estabelecidos pela tutela ambiental e, agregado a isso, mediante ações positivas em prol do ambiente. Portanto, o ambiente acaba tomando posição de extrema importância no ordenamento jurídico brasileiro.

A consagração da proteção ambiental na Constituição traz para o ordenamento jurídico um duplo aspecto de observância. De um lado, a instituição do direito fundamental ao ambiente, dotado de subjetividade e, consequentemente, passível de expressar pretensões judiciais. Por outro lado, mediante sua estrutura, não prescinde da consideração do cumprimento de deveres, tanto pelo Estado $^{57}$ como pela coletividade, com a finalidade de propiciar o adequado cumprimento da norma ambiental que não se basta apenas na configuração de um conteúdo substancial de reivindicação, dependendo, para o adimplemento desta tarefa, dos cidadãos e do Estado.

A solidariedade, revisitada nos direitos ditos de terceira dimensão, reforma as perspectivas de funcionalização do direito privado. Se outrora foi concebida a função social da propriedade

53 BRASIL. Supremo Tribunal Federal. Recurso Extraordinário 134297/SP. Recorrente: Estado de São Paulo. Recorridos: Paulo Ferreira Ramos e cônjuge. Relator: Ministro Celso de Mello. Brasília, 13 de junho de 1995. Disponível em: <http://redir.stf.jus.br/paginadorpub/paginador. jsp?docTP=AC\&doclD=207731>. Acesso em: 18 mar. 2018.

54 BRASIL. Supremo Tribunal Federal. Mandado de Segurança 22164/SP. Impetrante: Antônio de Andrade Ribeiro Junqueira. Impetrado: Presidente da República. Relator: Ministro Celso de Mello. Brasília, 30 de outubro de 1995. Disponível em: <http://redir.stf.jus.br/paginadorpub/ paginador.jsp?docTP=AC\&doclD=85691>. Acesso em: 18 mar. 2018.

55 BENJAMIN, Antônio Herman. Direito constitucional ambiental brasileiro. In: CANOTILHO, José Joaquim Gomes; LEITE, José Rubens Morato. Direito constitucional ambiental brasileiro. 6. ed. São Paulo: Saraiva, 2015, p. 139.

56 CANOTILHO, José Joaquim Gomes; MOREIRA, Vital. Constituição da República Portuguesa anotada, volume 1. São Paulo; Coimbra: Editora Revista dos Tribunais; Coimbra Editora, 2007, p. 847.

$57 \mathrm{O}$ artigo $225, \S 1^{\circ}$ da Constituição, quanto a isso, estabelece deveres ambientais do Estado em um rol não taxativo. 
e, posteriormente, a função social da empresa, tal ideal acaba necessitando ter agregado em seu conteúdo a perspectiva da funcionalização ambiental. Trata-se de característica proveniente da reunião dos objetivos social e ambiental na mesma direção, como se depreende do ordenamento jurídico. Daí a teorização sobre o surgimento do Estado Socioambiental, pautando-se pela inclusão do sistema normativo da tutela ambiental em observância ao bem-estar individual e coletivo. ${ }^{58}$

Com o direito fundamental ao ambiente e esta perspectiva de caráter solidário, pautada na dependência da atuação, além do Estado, também da coletividade, para sua concretização, devese reconsiderar a ideia de função social da propriedade para compreender, em seu conteúdo, os aspectos ambientais inerentes aos deveres fundamentais ambientais. A funcionalização da propriedade, assim, acaba convolada pelo direito fundamental ao ambiente com vistas a formar a ideia de função socioambiental da propriedade, sobretudo em se tratando de bens de produção, de forma a consolidar a funcionalização socioambiental das empresas.

\subsection{FUNÇÃO SOCIOAMBIENTAL DA EMPRESA: O AMBIENTE NA PERSPEC- TIVA FUNCIONALISTA DA EMPRESA}

É com os direitos de terceira dimensão, concebidos como direitos de solidariedade ou fraternidade, que a funcionalização do direito em favor da sociedade atinge o ápice no direito contemporâneo, como exemplifica o direito fundamental ao ambiente. Nestes casos, a solidariedade assume uma perspectiva coletiva, de titularidade comum e acarreta na responsabilidade de todos. ${ }^{59}$

Disso se observa que o ambiente passa a adquirir posição relevante no ordenamento jurídico, estabelecendo uma das diretrizes para a qual se direciona o Estado. Conjugar a propriedade aos ditames sociais deixou de ser um dos únicos requisitos a se observar, uma vez que consiste como meta do Estado, igualmente, o alcance de medidas ambientais com vistas a efetivar na maior plenitude possível o direito fundamental ao ambiente.

A propriedade, portanto, passa a ser conjugada não somente aos princípios de justiça social, vez que contém em sua estrutura, como critério de legitimação, também os requisitos da tutela ambiental que aparecem como dever fundamental na Constituição e somam-se às diretrizes do país, mormente quanto à solidariedade, conforme previsão no artigo $3^{\circ}$, inciso I da Constituição. Um

58 SARLET, Ingo Wolfgang; FENSTERSEIFER, Tiago. Direito constitucional ambiental: constituição, direitos fundamentais e proteção do ambiente. 3. ed. São Paulo: Editora Revista dos Tribunais, 2013, p. 103-104. Sobre a teorização acerca do Estado Socioambiental, Fensterseifer menciona haver uma convergência de objetivos sociais e ambientais no mesmo programa jurídico-político voltado ao desenvolvimento humano, tratandose de um Estado que não deixa de ser liberal ou social, aliando estas conquistas com a tutela dos emergentes direitos transindividuais (FENSTERSEIFER, Tiago. Direitos fundamentais e proteção do ambiente: a dimensão ecológica da dignidade humana no marco jurídico constitucional do estado socioambiental de direito. Porto Alegre: Livraria do Advogado Editora, 2008, p. 94/97).

59 LUCAS, J. de. La polémica sobre los deberes de solidaridad: el ejemplo del deber de defensa y su posible concreción en un servicio civil. Revista del Centro de Estudios Constitucionales, v. 19, p. 9-88, 1994, p. 23. 


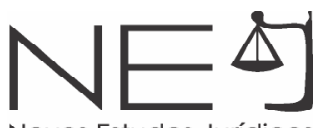

exemplo disso é a obrigação de harmonizar o uso da propriedade com finalidades econômicas e sociais incluindo a preservação da flora, da fauna, das belezas naturais, do equilíbrio ecológico e do patrimônio histórico e artístico, além do impedimento da poluição do ar e da água (artigo 1.128, §1 do Código Civil). Recai por sobre o direito da propriedade não somente a sua função social, estando igualmente limitado pela função ambiental. ${ }^{60}$ Assim, a função socioambiental da propriedade acaba surgindo como um dever que garante o direito de propriedade. ${ }^{61} \mathrm{Com}$ isso não se quer dizer que a função social deixa de ter importância ou deva ser esquecida. Pelo contrário, é com a junção das funcionalizações social e ambiental que se poderá alcançar os critérios que embasam as limitações ao direito de propriedade assegurado pela norma constitucional vigente.

A funcionalização socioambiental não se limita, porém, somente ao instituto da propriedade, tal como as imposições sobre bens destacados pelo artigo 1.128 do Código Civil. A vinculação finalística da função socioambiental atinge, igualmente, as empresas. Como se fundamentou alhures a respeito da imprescindibilidade de que a atividade empresarial observasse os ditames próprios à função social, o reconhecimento do ambiente como direito fundamental e como diretriz adotada pela Constituição acaba do mesmo modo condicionando as empresas mediante a imposição de deveres externos positivos e negativos, tanto de não atentar contra o ambiente como de agir em favor de sua tutela.

Assim está constitucionalizado no artigo 170, inciso $\mathrm{VI}$, onde consta como um dos princípios conformadores da ordem econômica a defesa do ambiente. Princípio este que, observado conjuntamente com o direito fundamental ao ambiente (artigo 225, também da Constituição), bem como com o conteúdo da função social da empresa, leva à conclusão de que, atualmente, a funcionalização da empresa necessita atender aos parâmetros sociais e ambientais. A defesa do ambiente, tal como positivado no mencionado artigo 170, revela-se, outrossim, com indispensabilidade à realização do fim da ordem econômica de assegurar uma existência digna a todos. ${ }^{62}$

Não se quer dizer, entretanto, que a defesa do ambiente, considerando seu contexto associado aos ditames da função social, dando forma à função socioambiental da empresa, implique uma primazia hierárquica da tutela ambiental sobre todo e qualquer princípio da ordem econômica e outras disposições normativas. De certo que a valorização e a preocupação com o futuro, por meio das questões ambientais, não podem implicar uma plena desconsideração das condições de existência, progresso e desenvolvimento do ser humano, levando em conta que as

60 KRELL, Andreas J. A relação entre a proteção ambiental e função social da propriedade nos sistemas jurídicos brasileiro e alemão. In: SARLET, Ingo Wolfgang. Estado socioambiental e direitos fundamentais. Porto Alegre: Livraria do Advogado Editora, 2010, p. 175. A título de exemplo, o artigo 186, inciso II, da Constituição condiciona a função social ao cumprimento de objetivos de proteção ambiental, ao estabelecer o uso racional dos recursos naturais disponíveis e a preservação do ambiente.

61 HUMBERT, Georges Louis Hage. Direito urbanístico e função socioambiental da propriedade imóvel urbana. Belo Horizonte: Fórum, 2009, p. 122.

62 GRAU, Eros Roberto. A ordem econômica na Constituição de 1988: interpretação e crítica. 18. ed. São Paulo: Malheiros, 2017, p. 248-249. 
atividades econômicas objetivam ao atendimento do conjunto de princípios insertos no artigo 170 da Constituição. ${ }^{63}$

A esse respeito decorre a conclusão de que as temáticas social e ambiental devem andar conjuntamente na funcionalização da atividade empresarial. Ademais, assim como a função social da empresa não buscava publicizar a atividade empresarial, de igual forma a função socioambiental não pretende paralisar o funcionamento das empresas. Objetiva-se, por meio da concepção da função socioambiental da empresa, demonstrar que, aos parâmetros vinculadores da justiça social presentes na funcionalização social da propriedade, é agregada a tutela ambiental com base na estrutura do direito fundamental ao ambiente e deveres que lhes são próprios, consoante a irradiação do mencionado direito ao longo do texto constitucional e da legislação infraconstitucional.

Vale mencionar que a proteção do ambiente assume contornos de proveitos externos direcionados à coletividade, mas não deixa de conter benefícios próprios às empresas, o que pode ser exemplificado pela preocupação com a utilização de matéria-prima exteriorizada com a conservação dos recursos naturais. ${ }^{64}$ Vê-se, portanto, que a função socioambiental se ajusta aos objetivos do direito fundamental ao ambiente, essencialmente na imposição de deveres fundamentais àqueles que assumem atividades empresariais, sem deixar de conter vantagens para as próprias empresas.

Não se busca uma desvinculação do objetivo principal das empresas pautado na obtenção do lucro. O que ocorre é uma ampliação dos deveres da atividade empresarial, outrora funcionalizados pelos objetivos de cunho social, para albergar em seu seio de deveres a tutela ambiental. As empresas passam a considerar a tríade pautada nos objetivos econômico, social e ambiental e, por consequência, necessitam estar alinhadas ao conceito de desenvolvimento sustentável. ${ }^{65}$

A funcionalização socioambiental das empresas nem mesmo remete à eliminação ou à diminuição de lucros empresarias, mas pugna pela vinculação da atividade empresarial aos fins sociais e ambientais determinados pela legislação constitucional e infraconstitucional, lembrando que isso poderá ocorrer por diversos meios, tais como normas de comando e controle aliadas a ferramentas de compliance e métodos win-win mediante a obtenção de retornos econômicos conjugados à qualidade

63 LUPION, Ricardo. Proteção ao meio ambiente e desenvolvimento sustentável. Direitos Fundamentais e Justiça, v.2, n. 3, p. 139-166, abr./jun. 2008, p. 143.

64 SARAIVA, Carolina Zenha. A ordem econômica constitucional e os limites à atuação dos órgãos de administração da sociedade anônima. 2013. 141 f. Dissertação (Mestrado em Fundamentos Constitucionais do Direito Público e do Direito Privado) - Faculdade de Direito, Pontifícia Universidade Católica do Rio Grande do Sul (PUCRS), Porto Alegre, 2013, p. 115. A autora propõe, especialmente nas páginas 113 a 120 de seu trabalho, uma vinculação da atividade empresarial para concretização de objetivos econômicos com a tutela do ambiente.

65 PEREIRA, Henrique Viana; MAGALHÃES, Rodrigo Almeida. A função social das sociedades transnacionais. In: BENACCHIO, Marcelo; VAILATTI, Diogo Basílio; DOMINIQUINI, Eliete Doretto. A sustentabilidade da relação entre empresas transnacionais e Direitos Humanos. Curitiba: CRV, 2016, p. 66. Seguindo o objetivo final do artigo, vale mencionar, segundo os autores, que o cumprimento de deveres por parte das empresas multinacionais não deveria ser sobrecarregado em relação ao das demais sociedades, sob pena de desestimular as idas e vindas das empresas, além de tornar a atividade mais cara (PEREIRA, Henrique Viana; MAGALHÃES, Rodrigo Almeida. A função social das sociedades transnacionais. In: BENACCHIO, Marcelo; VAILATTI, Diogo Basílio; DOMINIQUINI, Eliete Doretto. A sustentabilidade da relação entre empresas transnacionais e Direitos Humanos. Curitiba: CRV, 2016, p. 68). 


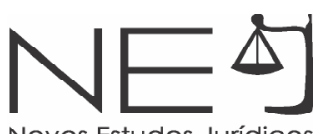

ambiental, como na adoção de políticas de inovação e responsabilidade ambiental com vistas à cooperação, ao compartilhamento de responsabilidades e à procura colaborativa por soluções. ${ }^{66}$

Assim, a função socioambiental advém da interpretação da norma ambiental, principalmente com a concretização do direito fundamental ao ambiente que consolida não somente o primado subjetivo, mas também deveres fundamentais que alcançam as pessoas jurídicas. Quanto à funcionalização das empresas, consoante se remeter a bens de produção, subsiste a função socioambiental de sua atividade, não podendo mais se referir exclusivamente às finalidades sociais do seu exercício.

Como assinala Derani, considerando que a base natural da vida imprime novos objetivos na política econômica, a positivação do direito fundamental ao ambiente ilumina o desenvolver da ordem econômica impondo a sustentabilidade. ${ }^{67}$ Portanto, tem-se que a política econômica, para estar juridicamente adaptada aos ditames constitucionais, deverá zelar no desenvolvimento, pela proteção ambiental e, consequentemente, pela qualidade de vida da população, procurando alcançar a dignidade da vida humana.

O Projeto de Lei 1572/201168, que pretende instituir o Código Comercial, capta a ideia dos deveres ambientais ao mencionar que o cumprimento da função social se dá, dentre outras formas, mediante a adoção de práticas empresariais sustentáveis voltadas à proteção do ambiente. ${ }^{69}$ No caso, como o projeto de lei situa a tutela ambiental no contexto da função social da empresa, importante destacar que tais objetivos ambientais perpassam o caráter do âmbito social e não prescindem da clara menção à função socioambiental como meio de demonstrar a importância de sua consolidação no Estado Socioambiental. Além disso, ainda que o entendimento da função socioambiental da empresa já se faça presente no ordenamento jurídico brasileiro, o projeto de lei mencionado teria importante efeito pedagógico para dirimir dúvidas a respeito do tema e reforçar seu conteúdo em legislação específica do direito privado.

A Arguição de Descumprimento de Preceito Fundamental (ADPF) 101, a despeito de não mencionar explicitamente o termo função socioambiental da empresa, não deixa de considerar a vinculação da livre concorrência e da livre iniciativa aos preceitos do direito fundamental ao ambiente. No caso, entendeu-se pela proibição de importação de pneus usados de qualquer espécie, incluídos os remoldados, por gerarem um acúmulo sem destinação ambientalmente adequada dos resíduos decorrentes do descarte, que contam com altos níveis tóxicos e causam graves danos ao ambiente,

66 FIORINO, Daniel J. The new environmental regulation. Cambridge: The MIT Press, 2006, p. $16 / 223$.

67 DERANI, Cristiane. Direito ambiental econômico. 3. ed. São Paulo: Saraiva, 2008, p. 227.

68 BRASIL. Câmara dos Deputados. Projeto de Lei 1572/2011. Disponível em: <http://www.camara.gov.br/ proposicoesWeb/prop_mostrarintegr a;jsessionid=DBCA71ED66FB97F657B57BC62242B00A. proposicoesWebExterno1?codteor=888462\&filename=PL+1572/2011>. Acesso em: 27 ago. 2018.

69 Conforme a redação original do projeto: "Art. $7^{\circ}$. A empresa cumpre sua função social ao gerar empregos, tributos e riqueza, ao contribuir para o desenvolvimento econômico, social e cultural da comunidade em que atua, de sua região ou do país, ao adotar práticas empresariais sustentáveis visando à proteção do meio ambiente e ao respeitar os direitos dos consumidores, desde que com estrita obediência às leis a que se encontra sujeita." 
além de se tratar de uma questão de saúde pública no que diz respeito à proliferação de doenças. Reconheceu-se, com isso, a imposição ao comércio e à indústria da responsabilidade pela melhoria do bem-estar geral, do que se extrairia a incompatibilidade com a permissão ou autorização para importação de pneus usados. ${ }^{70}$

Além da ADPF 101, pode-se ilustrar o reconhecimento da função socioambiental da empresa pela negativa de referendo do Tribunal Pleno do Supremo Tribunal Federal à medida liminar concedida na Ação Direta de Inconstitucionalidade (ADI) 3540, consolidando a possibilidade de supressão de vegetação em áreas de preservação permanente nos casos de utilidade pública ou de interesse social, como fora introduzido por meio de Medida Provisória no antigo Código Florestal (Lei 4.771/1965) ${ }^{71}$. No voto do Ministro Relator Celso de Mello, reconheceu-se a possibilidade de execução de obras ou serviços nas áreas de preservação permanente sem observância do princípio da reserva de lei formal, com base na adoção do critério interpretativo do desenvolvimento sustentável, observado como meio equilibrador das exigências da economia e do setor ambiental. Conforme o Ministro, as normas discutidas na $A D I$ inclusive favoreceram a tutela do ambiente por propiciar o controle pelo Estado das atividades desenvolvidas nas áreas de preservação do ambiente. Com efeito, importante destacar na decisão o atrelamento entre a ordem econômica e o ambiente, sobretudo no entendimento da viabilidade dos mecanismos impostos pelo Código Florestal, então contestados, como medida balizadora da atividade empresarial.

De acordo com o estudado a respeito do reconhecimento da funcionalização ambiental da atividade empresarial e tendo por exemplos as decisões proferidas pelo Supremo Tribunal Federal, entende-se que a função socioambiental da empresa condiciona a atividade empresarial para o alcance dos fins coletivos não somente sociais, mas também ambientais, sendo relevante o reconhecimento do duplo aspecto, social e ambiental, como forma de validar juridicamente o direcionamento dos esforços do Estado Socioambiental para o cumprimento das normas constitucionais que estabelecem as execuções de suas políticas públicas e fixam às empresas deveres próprios de proteção ambiental.

Fica ressaltado, pela consideração das matérias social, ambiental e econômica, que não há uma supremacia de alguma das vertentes, subsistindo uma conciliação de fatores que não engessem a atividade empresarial a uma finalidade estritamente social ou unicamente ambiental. A Ação Civil Pública, ajuizada por associação de moradores e pelo Ministério Público Federal (MPF), que objetiva a demolição de construções, em maior parte de beach clubs, localizadas em áreas de uso comum em Jurerê Internacional, no litoral catarinense, traz mais uma amostra de como questões sociais e

70 BRASIL. Supremo Tribunal Federal. Arguição de Descumprimento de Preceito Fundamental 101 - DF. Requerente: Presidente da República. Relatora: Ministra Cármen Lúcia. Brasília, 24 de junho de 2009. Disponível em: <http://redir.stf.jus.br/paginadorpub/paginador. jsp?docTP=AC\&docID=629955>. Acesso em 28 ago. 2018.

71 Ressalvadas algumas modificações, a alteração e a supressão da vegetação nativa nas áreas de preservação permanente estão previstas no artigo $8^{\circ}$ do atual Código Florestal (Lei 12.651/2012), incluída a possibilidade quando se tratar de baixo impacto ambiental. 
ambientais aparecem não raras vezes de modo conjunto. Julgado pelo Tribunal Regional Federal da $4^{a}$ Região (TRF-4), a decisão de primeiro grau que decidira pela demolição de todos as construções foi reformada parcialmente, determinando-se a demolição apenas dos acréscimos definitivos ou provisórios realizados nas construções quando posteriores ao ano de 2005, ano de realização do Termo de Ajustamento de Conduta (TAC), que impossibilitava qualquer nova construção de alvenaria ou provisória nos locais em que estão situados os beach clubs. ${ }^{72}$ A controvérsia, onde se vislumbra a ocorrência não somente de assuntos ambientais, mas, igualmente, das finalidades sociais dos beach clubs, mormente pela geração de empregos e renda para a região, ainda não está findada. Em sede de tutela provisória, o Superior Tribunal de Justiça suspendeu a ordem de demolição parcial ${ }^{73}$ e, ainda, será no mencionado Tribunal Superior que o feito transitará.

Esse último exemplo decorrente da Ação Civil Pública ajuizada demonstra que a função socioambiental da empresa encontra aplicabilidade no ordenamento jurídico, mas nem por isso deixa de carecer de um aprofundamento contínuo de sua interpretação para cada um dos casos concretos que surgirem e demandarem sua aplicação, sempre com vistas a uma relação não prejudicial entre as funções social e ambiental. É claro que essa relação possa vir a ser conflituosa em alguns casos, porém ambas as funções se fundamentam constitucionalmente e devem ser levadas em consideração.

\section{CONSIDERAÇÕES FINAIS}

A abordagem proposta neste estudo foi a de dispor sobre os fundamentos, o conceito e a aplicação da função socioambiental das empresas. Como se observou, a funcionalização do direito privado gerou ao longo de seu desenvolvimento jurídico, deixando-se de lado, por ora, as discussões pré-jurídicas, o reconhecimento da função social dos bens de produção e, portanto, a importância de que a ordem econômica vinculasse a atividade empresarial ao cumprimento de objetivos destinados a beneficiar a sociedade. Se, de início, ficaram demonstrados os conceitos filosóficos, sociológicos e políticos da ideia de função social da propriedade com base em autores como Duguit, Renner e Comte, posteriormente foi considerada a função social da propriedade, sobretudo dos bens de produção, a alcançar e a condicionar a atividade empresarial.

Com a constitucionalização do direito ao ambiente, alçado ao status de direito fundamental pela Constituição de 1988, foi fundamentada a composição do que se denominou de Estado

72 BRASIL. Tribunal Regional Federal da $4^{a}$ Região. Apelação Cível 5026468-07.2014.4.04.7200. Apelante: Ministério Público Federal e outros. Apelados: Ministério Público Federal e outros. Relatora: Desembargadora Federal Vânia Hack de Almeida. Disponível em: <https:// jurisprudencia.trf4.jus.br/pesquisa/inteiro_teor.php? orgao=1\&numero_gproc=40000220532\&versao_gproc=12\&crc_gproc $=7$ ed649fd\&termos Pesquisados=IGJIYWNoIGNsdWJzIGp1cmVyZSA=>. Acesso em: 26 set. 2018.

73 BRASIL. Superior Tribunal de Justiça. Tutela provisória 1254/SC. Requerente: CIACOI - Administração de Imóveis LTDA. Requerido: Associação de proprietários e moradores de Jurerê Internacional - AJIN e outros. Ministro Humberto Martins. Brasília, 20 de janeiro de 2018. Disponível em: <https://ww2.stj.jus.br/processo/ revista/documento/mediado/?componente=MON\&sequencial=79853311\&num_registro=2018 00118090\&data $=20180202 \&$ tipo=0\&formato=PDF>. Acesso em: 26 set. 2018. 
Socioambiental de Direito. Assim, não haveria mais como conceber a estrutura da funcionalização do direito única e exclusivamente com fins sociais por parte das empresas. É que a estrutura do direito fundamental constitucionalizada no artigo 225, em que se assenta seu marco jurídico-normativo, impôs uma série de deveres fundamentais destinados à coletividade de forma a alcançar, igualmente, as empresas.

Isso significa dizer que o outrora Estado Social, assim chamado em decorrência dos direitos de cunho social, ditos de igualdade, convolou-se para o Estado Socioambiental, que considera, também, a norma constitucional ambiental como matriz para a geração de deveres do Estado e da coletividade. Não mais seria possível dizer somente em uma função social da empresa quando no ordenamento jurídico e, principalmente no texto normativo constitucional, o ambiente passa a ser um direito fundamental com força de princípio regente da ordem econômica. Por isso, antes que uma função social, o que se tem é a função socioambiental da atividade empresarial.

Mesmo assim, como foi possível observar, a fundamentação da função socioambiental da empresa não deixa de ter raízes no conteúdo da função social da propriedade, posteriormente concebida como função socioambiental. Contém em sua materialidade a justificativa de que as pessoas jurídicas que desempenham atividades empresariais e, portanto, são vinculadas a bens de produção, também devem cumprir com deveres ambientais, os quais são concebidos, em caráter geral, no artigo 225 da Constituição.

Assim, o direito fundamental ao ambiente se irradia pelo complexo normativo e alcança a ordem econômica para impor, no âmbito do direito privado, os deveres de proteção ambiental que se apresentam em uma de suas formas como a função socioambiental da empresa.

\section{REFERÊNCIAS}

ALEXY, Robert. Teoria dos direitos fundamentais. Tradução de Virgílio Afonso da Silva. 2. ed. São Paulo: Malheiros Editores, 2011.

BENJAMIN, Antônio Herman. Direito constitucional ambiental brasileiro. In: CANOTILHO, José Joaquim Gomes; LEITE, José Rubens Morato. Direito constitucional ambiental brasileiro. 6. ed. São Paulo: Saraiva, 2015.

BOYD, David. The environmental rights revolution: a global study of constitutions, human rights, and the environment. Vancouver: UBC Press, 2012.

BRASIL. Câmara dos Deputados. Projeto de Lei 6960/2002. Disponível em: <http://www.camara.gov.br/proposicoesWeb/ fichadetramitacao?idProposicao=56549>. Acesso em: 17 de agosto de 2018.

BRASIL. Câmara dos Deputados. Projeto de Lei 1572/2011. Disponível em: <http://www.camara.gov.br/proposicoesWeb/ prop_mostrarintegra;jsessionid=DBCA71ED66FB97F657B57BC62242B00A. proposicoesWebExterno1? codteor $=888462 \& \mathrm{f}$ ilename $=P L+1572 / 2011>$. Acesso em: 27 ago. 2018.

BRASIL. Constituição da República Federativa do Brasil de 1988. Diário Oficial da União. Poder Legislativo, Brasília, DF, 05 out 1988 , p. 1. 
BRASIL. Lei nº 6.404, de 15 de dezembro de 1976. Dispõe sobre as Sociedades por Ações. Diário Oficial. Poder Executivo, Brasília, DF, 17 dez. 1976, p. 1.

BRASIL. Lei n 10.406, de 10 de janeiro de 2002. Institui o Código Civil. Diário Oficial da República Federativa do Brasil. Congresso Nacional, Brasília, DF, 11 jan. 2002, p. 1.

BRASIL. Lei no 12.651, de 25 de maio de 2012. Dispõe sobre a proteção da vegetação nativa; altera as Leis nos 6.938, de 31 de agosto de 1981, 9.393, de 19 de dezembro de 1996, e 11.428, de 22 de dezembro de 2006; revoga as Leis nos 4.771, de 15 de setembro de 1965, e 7.754, de 14 de abril de 1989, e a Medida Provisória no 2.166-67, de 24 de agosto de 2001; e dá outras providências. Diário Oficial da República Federativa do Brasil. Congresso Nacional, Brasília, DF, 28 maio 2012, p. 1.

BRASIL. Superior Tribunal de Justiça. AgRg no Agravo de Instrumento n 1.022.464 - SP. Agravante: Cipatex Impregnadora de Papéis e Tecidos LTDA. Agravado: Calçados E G M LTDA - Microempresa. Relator: Ministro Aldir Passarinho Júnior. Brasília, 02 de junho de 2009. Disponível em: <https://ww2.stj.jus.br/processo/revista/documento/mediado/? componen te $=$ ATC\&sequencial $=5301121 \&$ num_registro $=200800459448 \&$ data $=20090629 \&$ tipo $=5 \&$ formato $=P D F>$. Acesso em: 20 ago. 2018.

BRASIL. Superior Tribunal de Justiça. Recurso Especial n 363.206 - MG. Recorrente: Fazenda Pública do Estado de Minas Gerais. Recorrido: Royal Minas Distribuidora LTDA. Relator: Ministro Humberto Martins. Brasília, 04 de maio de 2010. Disponível em: https://ww2.stj.jus.br/processo/revista/documento/mediado/?componente=ATC\&sequencial $=9876145 \&$ num_registro $=200101482710 \&$ data $=20100521 \&$ tipo $=5 \&$ formato=PDF. Acesso em: 20 ago. 2018.

BRASIL. Superior Tribunal de Justiça. Tutela provisória 1254/SC. Requerente: CIACOI - Administração de Imóveis LTDA. Requerido: Associação de proprietários e moradores de Jurerê Internacional - AJIN e outros. Ministro Humberto Martins. Brasília, 20 de janeiro de 2018. Disponível em: <https://ww2.stj.jus.br/processo/revista/documento/mediado/? compo nente $=$ MON\&sequencial $=79853311 \&$ num_registro $=201800118090 \&$ data $=20180202 \&$ tipo $=0 \&$ formato $=$ PDF $>$. Acesso em: 26 set. 2018.

BRASIL. Supremo Tribunal Federal. Ação Direta de Inconstitucionalidade 1950 - SP. Requerente: Confederação Nacional do Comércio - CNC. Requerido: Governador do Estado de São Paulo. Requerida: Assembleia Legislativa do Estado de São Paulo. Relator: Ministro Eros Grau. Brasília, 03 de novembro de 2015. Disponível em: < http://redir.stf.jus.br/ paginadorpub/ paginador.jsp?docTP=AC\&doclD=2668080>. Acesso em: 20 ago. 2018.

BRASIL. Supremo Tribunal Federal. Arguição de Descumprimento de Preceito Fundamental 101 - DF. Requerente: Presidente da República. Relatora: Ministra Cármen Lúcia. Brasília, 24 de junho de 2009. Disponível em: <http://redir.stf. jus.br/paginadorpub/paginador.jsp? docTP=AC\&doclD=629955>. Acesso em: 28 ago. 2018.

BRASIL. Supremo Tribunal Federal. Mandado de Segurança 22164/SP. Impetrante: Antônio de Andrade Ribeiro Junqueira. Impetrado: Presidente da República. Relator: Ministro Celso de Mello. Brasília, 30 de outubro de 1995. Disponível em: <http://redir.stf.jus.br/ paginadorpub/paginador.jsp?docTP=AC\&docID=85691 >. Acesso em: 21 ago. 2018.

BRASIL. Supremo Tribunal Federal. Recurso Extraordinário 134297/SP. Recorrente: Estado de São Paulo. Recorridos: Paulo Ferreira Ramos e cônjuge. Relator: Ministro Celso de Mello. Brasília, 13 de junho de 1995. Disponível em: <http://redir.stf. jus.br/paginadorpub/paginador .jsp?docTP=AC\&docID=207731 >. Acesso em: 21 ago. 2018.

BRASIL.Tribunal Regional Federalda4ªRegião.ApelaçãoCível5026468-07.2014.4.04.7200.Apelante:MinistérioPúblicoFederal eoutros. Apelados: Ministério Público Federal e outros. Relatora: Desembargadora Federal Vânia Hack de Almeida. Disponível em: $\quad$ https://jurisprudencia.trf4.jus.br/pesquisa/inteiro_teor.php?orgao $=1 \&$ numero_gproc $=40000220532 \& v e r s a o_{-}$ gproc $=12 \& \mathrm{crc} \_$gproc $=7$ ed649fd\&termosPesquisados $=\mid$ GJIYWNoIGNsdWJzIGp1cmVyZSA=>. Acesso em: 26 set. 2018.

CANOTILHO, José Joaquim Gomes; MOREIRA, Vital. Constituição da República Portuguesa anotada, volume 1. São Paulo; Coimbra: Editora Revista dos Tribunais; Coimbra Editora, 2007, p. 847. 
COMPARATO, Fabio Konder. Estado, Empresa e Função Social. Revista dos Tribunais, v. 732, p. 38-46, out. 1996 , p. 6. Disponível em: <http://www.pucrs.br/biblioteca/rtonline>. Acesso em: 16 ago. 2018.

COMPARATO, Fábio Konder. Função social da propriedade dos bens de produção. In: Comparato, Fábio Konder. Direito empresarial: estudos e pareceres. São Paulo: Saraiva, 1990.

COMTE, Auguste. A general view of positivism. Translated by J. H. Bridges. Cambridge: Cambridge University Press, 2009.

COMTE, Auguste. The Positive Philosophy of Auguste Comte. Translated and condensed by Harriet Martineau. Kitchener: Batoche Books, 2000.

CRETELLA NETO, José. Nova lei de falências e recuperação de empresas: lei no 11.101, de 09.02.2005. Rio de Janeiro: Forense, 2005.

DERANI, Cristiane. Direito ambiental econômico. 3. ed. São Paulo: Saraiva, 2008.

DUGUIT, Léon. Traité de Droit Constitutionnel. 2. ed. Tome Troisiéme. Paris: E. de Boccard, 1923.

FACCHINI NETO, Eugênio. A função social do direito privado. TIMM, Luciano Benetti; MACHADO, Rafael Bicca. Função Social do Direito. São Paulo: Quartier Latin, 2009.

FACCHINI NETO, Eugênio; ANDRADE, Fábio Siebeneichler de. A funcionalização do direito: a empresa e sua função social. In: STEINDORFER, Fabriccio; MIZUTA, Alessandra. Limitações constitucionais ao exercício da atividade econômica. Curitiba: Juruá, 2016.

FAZZIO JÚNIOR, Waldo. Nova lei de falência e recuperação de empresas. 2. ed. São Paulo: Atlas, 2005.

FENSTERSEIFER, Tiago. Direitos fundamentais e proteção do ambiente: a dimensão ecológica da dignidade humana no marco jurídico constitucional do estado socioambiental de direito. Porto Alegre: Livraria do Advogado Editora, 2008.

FIORINO, Daniel J. The new environmental regulation. Cambridge: The MIT Press, 2006.

FRAZÃO, Ana. Função social da empresa: repercussões sobre a responsabilidade civil de controlares e administradores de S/As. Rio de Janeiro: Renovar, 2011.

GAVIÃO FILHO, Anizio Pires. Direito fundamental ao ambiente. Porto Alegre: Livraria do Advogado, 2005.

GRAU, Eros Roberto. A ordem econômica na Constituição de 1988: interpretação e crítica. 18. ed. São Paulo: Malheiros, 2017.

GRAU, Eros Roberto. Lucratividade e função social das empresas sob controle do Estado. Revista de Direito Mercantil, Industrial, Econômico e Financeiro, v. XXIII, n. 55, p. 35-59, jul./set. 1984.

HESSE, Konrad. A força normativa da Constituição. Tradução de Gilmar Mendes. Porto Alegre: Sergio Antonio Fabris Editor, 1991.

HUMBERT, Georges Louis Hage. Direito urbanístico e função socioambiental da propriedade imóvel urbana. Belo Horizonte: Fórum, 2009.

KRELL, Andreas J. A relação entre a proteção ambiental e função social da propriedade nos sistemas jurídicos brasileiro e alemão. In: SARLET, Ingo Wolfgang. Estado socioambiental e direitos fundamentais. Porto Alegre: Livraria do Advogado Editora, 2010.

LUCAS, J. de. La polémica sobre los deberes de solidaridad: el ejemplo del deber de defensa y su posible concreción en un servicio civil. Revista del Centro de Estudios Constitucionales, v. 19, p. 9-88, 1994.

LUPION, Ricardo. Proteção ao meio ambiente e desenvolvimento sustentável. Direitos Fundamentais e Justiça, v.2, n. 3, p. 139-166, abr./jun. 2008. 
MEIRELLES, Hely Lopes. Direito administrativo brasileiro. 43. ed. São Paulo: Malheiros, 2018.

MILARÉ, Édis. Direito do ambiente. 9. ed. São Paulo: Editora Revista dos Tribunais, 2014.

MOURA, M. A. Função social do contrato. Revista dos Tribunais, v. 630, p. 247-249, abr. 1988.

NABAIS, José Casalta. O dever fundamental de pagar impostos. Coimbra: Livraria Almedina, 1998.

PÉREZ LUÑO, Antonio Enrique. Derechos Humanos, Estado de Derecho y Constitucion. 5. ed. Madrid: Tecnos, 1995.

PONTES DE MIRANDA. Comentários à Constituição de 1967: com a emenda n. 1, de 1969. Tomo V (arts. 153, §2 ${ }^{\circ}-159$ ).

2. ed. São Paulo: Editora Revista dos Tribunais, 1971.

RENNER, Karl. The institutions of private law and their social functions. Translated Agnes Schwarzschild. London: Routledge \& Kegan Paul Limited, 1949.

SARAIVA, Carolina Zenha. A ordem econômica constitucional e os limites à atuação dos órgãos de administração da sociedade anônima. 2013. 141 f. Dissertação (Mestrado em Fundamentos Constitucionais do Direito Público e do Direito Privado) - Faculdade de Direito, Pontifícia Universidade Católica do Rio Grande do Sul (PUCRS), Porto Alegre, 2013.

SARLET, Ingo Wolfgang; FENSTERSEIFER, Tiago. Direito Constitucional Ambiental: constituição, direitos fundamentais e proteção do ambiente. 3. ed. São Paulo: Editora Revista dos Tribunais, 2013.

SARLET, Ingo Wolfgang. A eficácia dos direitos fundamentais: uma teoria geral dos direitos fundamentais na perspectiva constitucional. 11. ed. Porto Alegre: Livraria do Advogado Editora, 2012.

SARLET, Ingo Wolfgang. Teoria geral dos direitos fundamentais. In: SARLET, Ingo Wolfgang; MARINONI, Luiz Guilherme; MITIDIERO, Daniel. Curso de direito constitucional. 6. ed. São Paulo: Saraiva, 2017.

SARLET, Ingo Wolfgang; FENSTERSEIFER, Tiago. Direito Constitucional Ambiental: constituição, direitos fundamentais e proteção do ambiente. 3. ed. São Paulo: Editora Revista dos Tribunais, 2013.

SCALZILLI, João Pedro; SPINELLI, Luis Felipe; TELLECHEA, Rodrigo. Recuperação de empresas e falência: teoria e prática na Lei 11.101/2005. São Paulo: Almedina, 2016.

TOMASEVICIUS FILHO, E. A função social da empresa. Revista dos Tribunais, v. 810, p. 33-50, abr. 2003. Disponível em: <http://www.pucrs.br/biblioteca/rtonline>. Acesso em: 16 ago. 2018.

TIMM, Luciano Benetti. As origens do contrato no novo Código Civil: uma introdução à função social, ao welfarismo e ao solidarismo contratual. Revista dos Tribunais, v. 844, p. 85-95, fev. 2006. Disponível em: <http://www.pucrs.br/ biblioteca/rtonline>. Acesso em: 15 ago. 2018.

TRINDADE, Antônio Augusto Cançado. Tratado de Direito Internacional dos Direitos Humanos. 3 v. Porto Alegre: Sergio Antonio Fabris Editor, 2003.

VERFASSUNG des Deutschen Reichs. Bonn, 11 August 1919. Disponível em: <http://www.lwl.org/westfaelische-geschichte/ que/normal/que843.pdf>. Acesso em: 16 ago. 2018.

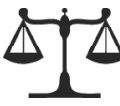

RECEBIDO EM: 25/09/2019

APROVADO EM: 14/11/2019 